\title{
DETERMINATION OF SOME METAL LEVELS IN WATER, SEDIMENT AND FISH SPECIES OF TERCAN DAM LAKE, TURKEY
}

\author{
GÜNEŞ, M. ${ }^{1,{ }^{*}}-$ SÖKMEN, T. Ö. ${ }^{1}-$ KIRICI, M. ${ }^{2}$ \\ ${ }^{1}$ Department of Occupational Health and Safety, Vocational School of Tercan, Erzincan Binali \\ Ylldirum University, 24100 Erzincan, Turkey \\ ${ }^{2}$ Department of Veterinary Health, Vocational School of Technical Sciences, Bingöl University, \\ 12000 Bingöl, Turkey \\ *Corresponding author \\ e-mail: gunesmuharrem@hotmail.com; phone: +90-533-318-1454; fax: +90-446-226-6665
}

(Received 23 $3^{\text {rd }}$ Jun 2019; accepted $16^{\text {th }}$ Oct 2019)

\begin{abstract}
This study aimed to determine the metal (Al, $\mathrm{As}, \mathrm{Cr}, \mathrm{Cu}, \mathrm{Fe}, \mathrm{Mn}, \mathrm{Ni}, \mathrm{Pb}$, and $\mathrm{Zn}$ ) levels in the gill, liver, and muscle tissues of some fish species, water and sediment samples taken from Tercan Dam Lake (Erzincan, Turkey). Initially, some physico-chemical parameters of the water such as temperature, $\mathrm{pH}$, and dissolved oxygen were measured, and the relationship was determined between these parameters and the metal levels detected in the water. According to the analysis conducted on the water and the sediment, the most frequent metal was determined to be Fe. During the analyses conducted in the water, $\mathrm{Pb}$ and $\mathrm{Zn}$ metals were not detected, and all metals were detected in the sediment. It was determined that metals accumulated to a higher degree in the liver and gill tissues compared to muscle tissues. The harmfulness of the metal amounts determined in the water, sediment, and fish tissues was evaluated by comparing them to the acceptable values determined by national and international institutions.
\end{abstract}

Keywords: accumulation, toxicity, Tercan Dam Lake, water contamination, physico-chemical parameters

\section{Introduction}

The aquatic ecosystem, being part of the biosphere, is a receiver and carrier environment for the waste water and used water in the system, it is more exposed to contamination compared to air and soil (Yarsan et al., 2000). Water, which is in a constant cycle on the earth, loses its environment as a result of mostly human activities. Consequently, the water contamination occurs. Undoubtedly, the leading contaminators are the metals, which are common in today's aquatic ecosystem and which cause high rates of toxicity in aquatic organisms. Metals in general have a particular significance among other chemical contaminators since they can emerge from very different sources, cause a vast amount of contamination, continuously affect the biological systems, andentering the food chain - can simply accumulate in developed living beings with increasing intensities (Erdoğrul and Ates, 2006).

Metals are carried towards waters by rock fragments through erosion, dust particles carried by the wind, volcanic activities, and forest fires. Metals dissolved in the water merge into the sediment by precipitating to the bottom, and thus, the metals accumulate at the sediment (Fergusson, 1990). The concentration of the metals accumulating at the sediment varies based on the ratio of the sediment particles, the size of the particles, and based on whether there are organic substances in the sediments. Since the sediment is an 
important accumulation environment for the metals, it is used in determining the metal contamination of the aquatic environments (Salomans et al., 1987).

The fish take the metals through nutrition, water, gills and skin from the external environment. The amount of the metals accumulating at different tissues of the fish vary according to the amount of metal in the environment, the type of the metal, the interaction duration of metal and the fish, the age and metabolic activities of the fish, the phase of its development, the physico-chemical characteristics of the water, tissues, and organs (Köse and Uysal, 2008). The metals received by the fish reach to the tissues and organs via blood path bonded to the carrier protein, and they reach high concentration levels through being bonded by the metal bonding proteins (Sönmez et al., 2016). Metals show their toxic effects on cell membranes, enzymes, and cell organelles in general (Kirici et al., 2017a). The toxicity of metals involves the interaction between the toxicological target and the free metal ions. Additionally, the cells (liver, renal tubular, gastrointestinal), which make metal transfer during their tasks, are the most toxic-effect-sensitive cells (Elbeshti et al., 2018).

Numerous studies have been conducted on the accumulation of metals in water, sediments, and fish (Moiseenko and Kudryavtseva, 2001; Al-Saadi et al., 2002; Özmen et al., 2004; Tekin-Özan et al., 2007; Tao et al., 2011; Tekin-Özan and Aktan, 2012; Başyiğit and Tekin-Özan, 2013; Kirici et al., 2013a, 2016a, 2017b). In this study, it was aimed at determining the metal ( $\mathrm{Al}, \mathrm{As}, \mathrm{Cr}, \mathrm{Cu}, \mathrm{Fe}, \mathrm{Mn}, \mathrm{Ni}, \mathrm{Pb}$, and $\mathrm{Zn}$ ) concentrations in the gills, livers, and muscle tissues of Grass carp (Ctenopharyngodon idella), Caner fish (Barbus capito), Common carp (Cyprinus carpio) and Tigris scraper (Capoeta umbla), which live in the Tercan Dam Lake-within the borders of Erzincan provincewater, sediment, and lake; it was also aimed at determining the relationship between metal levels in the water and the measured certain physico-chemical parameters of the water.

\section{Materials and methods}

\section{Research area}

Tercan Dam Lake is located $3 \mathrm{~km}$ to the Tercan district of Erzincan province (Turkey). The Dam Lake was inaugurated in 1988 for irrigation and energy. The lake has a surface area of $8.85 \mathrm{~km}^{2}$, a drainage volume of 178 million $\mathrm{m}^{3}$, and an irrigation area of 29725 ha. It is located between $39^{\circ} 44^{\prime} 2^{\prime \prime}$ north latitude and $40^{\circ} 26^{\prime} 40^{\prime \prime}$ east longitudes (Fig. 1). Tercan Dam Lake is fed by Tuzla Brook, Çirkiz Brook, Bülbül Brook and Pırnaşil Brook.

\section{Field studies}

The research study was conducted through samples taken from 3 stations between March 2018 - May 2018. The water $(500 \mathrm{~mL}$ water samples were taken from each station) and sediment samples (3 g sediment samples were taken from each station) were taken from each station 3 times in different days, which was repeated 3 times permonth. As per the fish samples (grass carp $(\mathrm{n}=22)$, Caner fish $(\mathrm{n}=21)$, Common carp $(n=25)$ and Tigris scraper $(n=29))$, they were obtained by means of fishermen fishing in the area. During the study, the temperature, $\mathrm{pH}$, and dissolved oxygen amount of the water were measured through the Jenco 6010 (Jenco Instruments Co. China) brand portable multi-parameter. The water, sediment, and fish samples taken from the lake 
were brought to the laboratories after being contained in sample containers under cold storage conditions. The water samples were treated with $\mathrm{HNO}_{3}$ with a $2 \%$ concentration ratio. The water samples were kept at $+4{ }^{\circ} \mathrm{C}$ until $(24 \mathrm{~h})$ they were analyzed. The sediment samples were taken through ekman spoonnet, being brought to the laboratory within propylene containers.

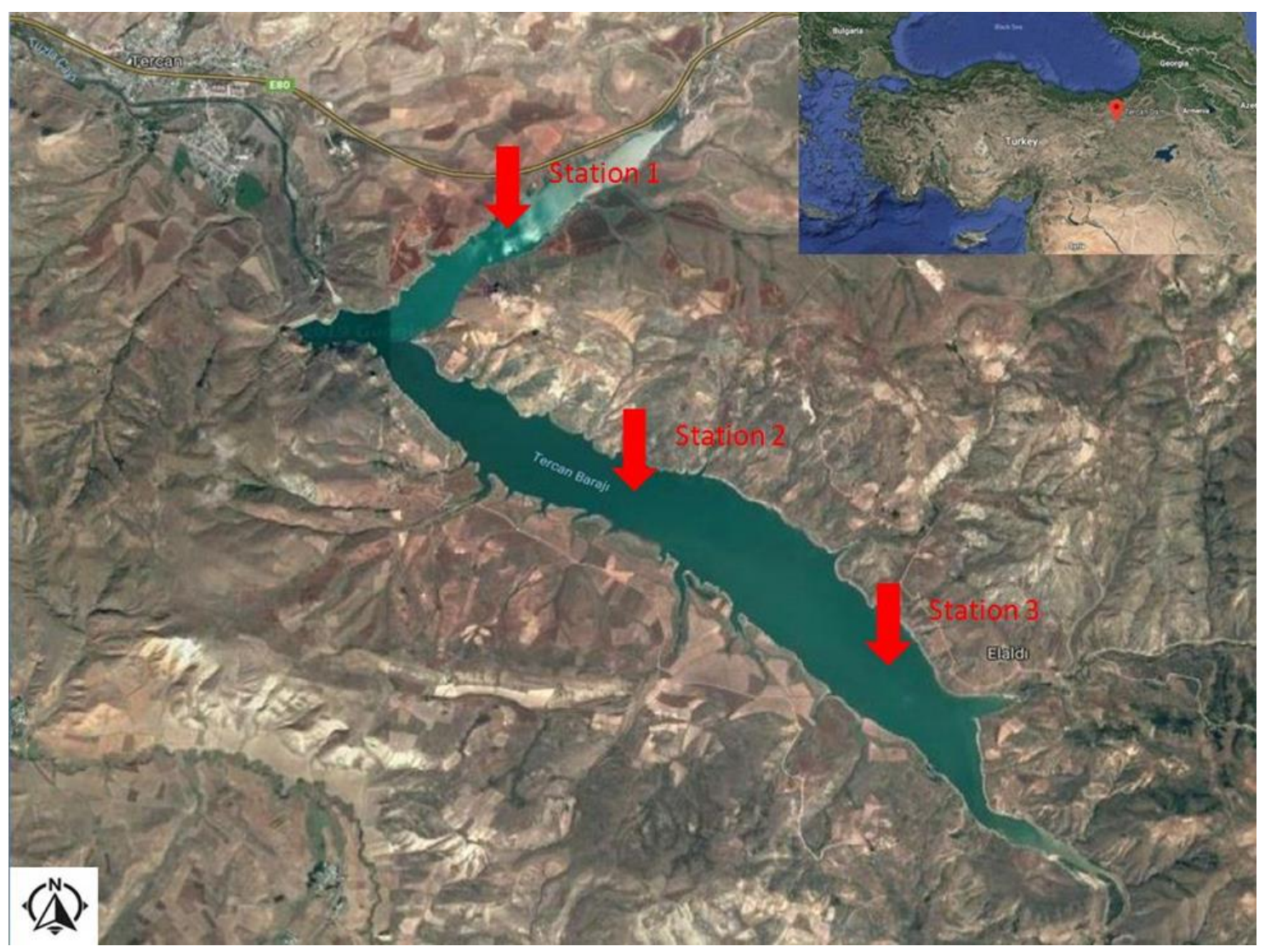

Figure 1. Tercan Dam Lake

\section{Laboratory studies}

The samples of water, sediment, and fish were brought to the Chemistry Laboratory of Erzincan University Basic Sciences Research and Application Center for laboratory studies. The weights of the fish were measured via scales and their total lengths were measured via measuring board with $\pm 1 \mathrm{~mm}$ precision. Subsequently, muscle, liver, and gill tissue samples of the fish were taken.

In order to determine the $\mathrm{Al}, \mathrm{As}, \mathrm{Cr}, \mathrm{Cu}, \mathrm{Fe}, \mathrm{Mn}, \mathrm{Ni}, \mathrm{Pb}$, and $\mathrm{Zn}$ accumulation concentrations in the muscle, gill, and liver tissues of the fish, 3-5 g samples were taken from each tissue. The tissue samples were put into heat-proof glass bottles and kept under $105^{\circ} \mathrm{C}$ for $24 \mathrm{~h}$ in the Drying Oven for drying, and subsequently they were left for cooling down for $24 \mathrm{~h}$. After pulverizing each sample and limiting them to $0.5 \mathrm{~g}$ via the precision scale, they were placed into teflon microwave tubes. Adding $7 \mathrm{ml} \mathrm{HNO}_{3}$ and $1 \mathrm{ml} \mathrm{H}_{2} \mathrm{O}_{2}$, they were kept at ambient temperature for $24 \mathrm{~h}$. The samples were shaken in the vortex for $10 \mathrm{~min}$, thus, they were mineralized. Placed into microwave tubes, the samples were burnt at $110^{\circ} \mathrm{C}$ at $700 \mathrm{~W}$ for $45 \mathrm{~min}$. After opening the samples in the fume cupboard, their weights were increased to $200 \mathrm{ml}$ by adding deionized 
water. Filtered through a teflon filter, the samples were made ready for the analysis. The metal analyses of the prepared samples were measured through ICP-MS device (Sökmen et al., 2018).

The sediment samples to be analyzed were taken from the lake via ekman spoonnet and placed into containers, and they were kept in deepfreeze until the analysis. For the measurement, $1 \mathrm{~g}$ was taken from each sample and placed into microwave solubilization tubes. Adding $5 \mathrm{ml} \mathrm{HNO}_{3}$ and $1 \mathrm{ml} \mathrm{H}_{2} \mathrm{O}_{2}$ into each tube, they were exposed to solubilization process in a microwave oven (Milestone Ethos Plus 2000). Taking the tubes out from the oven, they were cooled down at the ambient temperature and the solutions in the tubes were transferred into $25 \mathrm{ml}$ polypropylene volumetric flasks. The solution amounts in the volumetric flasks were completed to $25 \mathrm{ml}$ by adding distilled water. The metal analysis of the samples was conducted in the (Perkin Elmer, 5300 DV model) ICP-OES device. The metal analyses of the water samples were directly conducted. The detection limits of the elements were $\mathrm{Cd} 0.0012 \mathrm{ppm}, \mathrm{Cr} 0.0027 \mathrm{ppm}$, $\mathrm{Cu} 0.0069$ ppm, Fe 0.0381 ppm, Mn 0.001 ppm, Pb 0.0078 ppm, Zn 0.0015 ppm, Al 0.0057 ppm, and Ni 0.0048 ppm (Tekin-Özan and Kır, 2005).

\section{Statistical analyses}

The minimum-maximum values, arithmetic means, and standard deviation values of the results obtained in the study were calculated. Pearson Test was applied to determine the relationship between the physico-chemical parameters (temperature, $\mathrm{pH}$, and dissolved oxygen) of the water and metal amounts. All of the statistical calculations were conducted through SPSS 17 package program.

\section{Results and discussion}

In this study, the metal ( $\mathrm{Al}, \mathrm{As}, \mathrm{Cr}, \mathrm{Cu}, \mathrm{Fe}, \mathrm{Mn}, \mathrm{Ni}, \mathrm{Pb}$, and $\mathrm{Zn}$ ) concentrations were determined in the gill, liver, and muscle tissues of grass carp, Caner fish, common carp and Tigris scraper fish living in the water, sediment, and lake of the Tercan Dam Lake. Additionally, the relationship between the physico-chemical parameters and metal levels in the water was determined.

During the study, the water temperature, $\mathrm{pH}$ value, and dissolved oxygen amounts of the Tercan Dam Lake were measured and given in the Table 1. According to the Table 1, the highest temperature is $14.2{ }^{\circ} \mathrm{C}$, while the lowest is $8.3{ }^{\circ} \mathrm{C}$, and the mean temperature is $11.4{ }^{\circ} \mathrm{C}$.

The results of the metal analyses conducted in the Tercan Dam Lake are given in the Table 2. As the conclusion of the metal analyses conducted in the water, it was determined that the highest accumulated metal in the water was Fe metal. Besides, the $\mathrm{Pb}$ and $\mathrm{Zn}$ metals were under the analysis limitations. The ranking of the mean values of the accumulation in the water was determined as $\mathrm{Fe}>\mathrm{Al}>\mathrm{Ni}>\mathrm{As}>\mathrm{Cu}>\mathrm{Mn}>\mathrm{Cr}$. Reporting that the highest accumulated metal in the Habbaniyah Lake (Iraq) was Zn, Al-Saadi et al. (2002) stated that it was followed, respectively, by $\mathrm{Cu}, \mathrm{Pb}, \mathrm{Ni}, \mathrm{Mn}$ and $\mathrm{Cd}$ metals. It was also mentioned that the $\mathrm{Cd}, \mathrm{Co}, \mathrm{Hg}, \mathrm{Mo}$, and $\mathrm{Pb}$ were under the AAS analysis limitations. In a study conducted in the Texoma Lake by An and Kampbell (2003) it was mentioned that the highest metal concentrations in the water were $\mathrm{Na}$ and $\mathrm{Ca}$, and subsequently $\mathrm{Mg}$ and $\mathrm{K}$. In a study conducted in the Kovada Lake by TekinÖzan et al. (2004), Fe, Zn, and Mn were determined in the waters of the lake, and it was also determined that the levels of $\mathrm{Cu}, \mathrm{Cr}, \mathrm{Pb}$ and $\mathrm{Cd}$ were under the AAS analysis 
limitations. Similarly, in a study conducted in the Kovada Lake by K1r et al. (2007), it was determined that the most frequent metal encountered in the water was Fe. In a study conducted in the Taihu Lake (China), it was determined that the highest accumulated metal in the water was $\mathrm{Zn}$, while the least accumulated one was $\mathrm{Cd}$ (Tao et al., 2012). Similarly, in a study conducted in the Panjkora River (Pakistan), the highest accumulated metal in the water was $\mathrm{Zn}$, while the least accumulated metal was $\mathrm{Cd}$ (Ahmad et al., 2014).

Table 1. Maximum, minimum, mean and standard deviation values of the temperature, $\mathrm{pH}$, and dissolved oxygen values in the Tercan Dam Lake

\begin{tabular}{c|c|c|c}
\hline & Temperature & $\mathbf{p H}$ & Dissolved oxygen $\mathbf{( m g / L )}$ \\
\hline Minimum & 8.3 & 7.7 & 8.3 \\
Maximum & 14.2 & 8.1 & 9.2 \\
Mean & 11.4 & 7.9 & 8.7 \\
Standard deviation & 2.42 & 0.17 & 0.39 \\
\hline
\end{tabular}

Table 2. Maximum values, minimum values, mean values (ppb), and standard deviation values of the metal concentrations measured in the Tercan Dam Lake

\begin{tabular}{c|c|c|c|c|c|c|c|c|c}
\hline & Al & As & Cr & Cu & Fe & Mn & Ni & Pb* $^{*}$ & $\mathbf{Z n}^{*}$ \\
\hline Minimum & 2.167 & 1.430 & 0.003 & 0.112 & 4.737 & 0.045 & 0.459 & - & - \\
Maximum & 4.152 & 2.219 & 0.143 & 0.460 & 7.016 & 0.316 & 4.568 & - & - \\
Mean & 3.466 & 1.811 & 0.037 & 0.268 & 5.703 & 0.139 & 1.896 & - & - \\
Standard deviation & 0.921 & 0.229 & 0.024 & 0.089 & 0.965 & 0.023 & 0.743 & - & - \\
\hline
\end{tabular}

*Below the analysis limitations

As the conclusion of the metal analyses conducted in the waters of the Tercan Dam Lake and comparing the metal levels of the study to the acceptable heavy metal amounts in the water determined by the World Health Organization (WHO), Turkish Standards Institute (TSI), and Turkish Ministry of Food, Agriculture, and Livestock (MFAL), and United States Environmental Protection Agency (USEPA), it was determined that all metal levels were under the acceptable values.

Using the Pearson Test, the relationships were determined between the temperature, $\mathrm{pH}$, and dissolved oxygen amounts and the metal levels determined in the water, which are all given in the Table 3. According to this, there is a negative relationship between the temperature and the $\mathrm{Ph}$, and there is a positive relationship between temperature and dissolved oxygen. In other words, while the temperature increases, $\mathrm{pH}$ value decreases, and the dissolved oxygen amounts increase. There is a negative relationship between the $\mathrm{pH}$ and dissolved oxygen, in other words, while $\mathrm{pH}$ increases, the dissolved oxygen amounts decrease. The $\mathrm{pH}$ value has a negative relationship with $\mathrm{Cr}, \mathrm{Cu}$, and $\mathrm{Ni}$; while it has a positive relationship with $\mathrm{Al}, \mathrm{As}, \mathrm{Fe}$, and $\mathrm{Mn}$. While the dissolved oxygen has a negative relationship with $\mathrm{Al}, \mathrm{Cr}, \mathrm{Cu}$, and $\mathrm{Fe}$, it has a positive relationship with As, Mn, and Ni. Moreover, there are statistically significant differences between dissolved oxygen and As, between dissolved oxygen and $\mathrm{Cu}$, and between $\mathrm{Al}$ and $\mathrm{Ni}(<0.05)$. 
Table 3. Values of some physico-chemical parameters and metals measured in the waters of Tercan Dam Lake determined via Pearson test

\begin{tabular}{c|c|c|c|c|c|c|c|c|c|c}
\hline & Temperature & $\mathbf{p H}$ & $\begin{array}{c}\text { Dissolved } \\
\text { oxygen }\end{array}$ & $\mathbf{A l}$ & $\mathbf{A s}$ & $\mathbf{C r}$ & $\mathbf{C u}$ & $\mathbf{F e}$ & $\mathbf{M n}$ & $\mathbf{N i}$ \\
\hline Temperature & 1 & -0.569 & 0.457 & -0.403 & 0.433 & -0.049 & -0.267 & -0.221 & 0.380 & 0.491 \\
$\mathrm{pH}$ & & 1 & -0.035 & 0.519 & 0.367 & -0.258 & -0.106 & 0.591 & 0.213 & -0.249 \\
Dissolved oxygen & & & 1 & -0.647 & $0.753^{*}$ & -0.509 & $-0.731^{*}$ & -0.473 & 0.280 & 0.402 \\
$\mathrm{Al}$ & & & & 1 & -0.211 & 0.029 & 0.291 & 0.656 & -0.183 & $-0.695^{*}$ \\
$\mathrm{As}$ & & & & & 1 & -0.404 & -0.602 & 0.046 & 0.421 & 0.353 \\
$\mathrm{Cr}$ & & & & & & 1 & 0.467 & -0.226 & 0.065 & -0.002 \\
$\mathrm{Cu}$ & & & & & & & 1 & 0.243 & 0.050 & 0.058 \\
$\mathrm{Fe}$ & & & & & & & & 1 & 0.182 & -0.095 \\
$\mathrm{Mn}$ & & & & & & & & & 1 & 0.563 \\
$\mathrm{Ni}$ & & & & & & & & & & \\
\hline
\end{tabular}

$* 0.05$ significance level

The metal amounts determined in the sediment samples taken from the Tercan Dam Lake are given in Table 4. As the conclusion of the metal analyses on the sediment, it was determined that the highest accumulated metal in the lake waters was Fe, and the lowest one was As. According to the ranking of the mean values of the accumulation in the water, it was determined as $\mathrm{Fe}>\mathrm{Al}>\mathrm{Mn}>\mathrm{Cr}>\mathrm{Ni}>\mathrm{Zn}>\mathrm{Cu}>\mathrm{Pb}>\mathrm{As}$. In the study conducted in the Texoma Lake (USA), An and Kampbell (2003) determined that the metal accumulation mean values ranking was $\mathrm{Ca}>\mathrm{Al}>\mathrm{Fe}>\mathrm{K}>\mathrm{Mg}>\mathrm{Na}$. Özmen et al. (2004) conducted a research about some certain heavy metal accumulations in the Caspian Sea ( $\mathrm{Zn}, \mathrm{Fe}, \mathrm{Mn}, \mathrm{Ni}, \mathrm{Cu}, \mathrm{Cr}, \mathrm{Co}$ and $\mathrm{Pb}$ ). As the conclusion of the study, it was determined that the ranking of the major elements and heavy metal concentrations in the sediment was $\mathrm{Fe}>\mathrm{Mg}>\mathrm{Ca}>\mathrm{Mn}>\mathrm{Zn}>\mathrm{Ni}>\mathrm{Cr}>\mathrm{Cu}>\mathrm{Co}>\mathrm{Pb}$. In another study conducted in Uluabat Lake, Kurtoğlu (2006) detected that the heavy metals had a ranking such as $\mathrm{Pb}>\mathrm{Cu}>\mathrm{Cr}>\mathrm{Ni}>\mathrm{Cd}>\mathrm{Zn}$ in the sediment samples. In another study conducted in the Cauvery River (India), Venkatesha et al. (2012) examined heavy metals such as $\mathrm{Fe}, \mathrm{Zn}, \mathrm{Ni}, \mathrm{Mn}, \mathrm{Pb}, \mathrm{Cu}, \mathrm{Co}, \mathrm{Cd}$ and $\mathrm{Cr}$ in the sediment samples. As the conclusion of the study, it was determined that the highest accumulated metal in the sediment was $\mathrm{Fe}$. It was followed by, respectively, $\mathrm{Mn}, \mathrm{Cr}, \mathrm{Zn}, \mathrm{Ni}, \mathrm{Cu}, \mathrm{Pb}, \mathrm{Co}$, and $\mathrm{Cd}$ metals. In a different study conducted in Odiel River (Spain) by Usero et al. (2003), it was determined that the highest accumulated metal in the sediment was Fe. Usero et al. (2003) explained the reason that the metal that existed in the earth's crust at the highest level was Fe, that was why it was at higher levels in the lake, river, and sea sediment compared to other metals.

When the analysis results of the sediment samples taken from the Tercan Dam Lake were compared to the data of the American National Oceanic and Atmospheric Administration (NOAA), it was determined that all the metals were below the acceptable levels.

The number, total length, and weights of the fish caught by the help of the fishermen fishing in the region are given in Table 5. In the study, 22 grass carp fish were used with a length of $29.6 \pm 1.02 \mathrm{~cm}$, and weighting $409.4 \pm 13.64 \mathrm{~g}, 21$ Caner fish fish were used with a length of $43.2 \pm 5.11 \mathrm{~cm}$, and weighting $648.6 \pm 15.70 \mathrm{~g}$, while 25 common carp fish were used with a length of $31.2 \pm 1.46 \mathrm{~cm}$, and weighting $337.2 \pm 10.88 \mathrm{~g}$, and 29 Tigris scraper were used with a length of $32.8 \pm 2.48 \mathrm{~cm}$, and weighting $385.1 \pm 13.5 \mathrm{~g}$. 
Table 4. Maximum values, minimum values, mean values ( $\mathrm{mg} / \mathrm{kg}$ ), and standard deviation values of the metal concentrations measured in the Tercan Dam Lake sediment

\begin{tabular}{c|c|c|c|c|c|c|c|c|c}
\hline & Al & As & Cr & Cu & Fe & Mn & Ni & Pb & Zn \\
\hline Minimum & 799.091 & 0.001 & 2.931 & 2.149 & 863.582 & 31.474 & 1.169 & 2.426 & 1.550 \\
Maximum & 1131.294 & 0.041 & 66.099 & 14.533 & 7731.094 & 153.228 & 42.461 & 7.783 & 39.148 \\
Mean & 936.438 & 0.015 & 39.362 & 5.979 & 3816.004 & 102.253 & 17.944 & 4.588 & 17.701 \\
Standard deviation & 16.593 & 0.006 & 1.684 & 0.460 & 22.766 & 7.160 & 3.724 & 0.306 & 3.948 \\
\hline
\end{tabular}

Table 5. Weight and length averages of the fish caught

\begin{tabular}{c|c|c|c}
\hline Fish species & Total length $(\mathbf{c m})$ & Weight $\mathbf{( g )}$ & Fish number \\
\hline Grass carp (Ctenopharyngodon idella) & $29.6 \pm 1.02$ & $409.4 \pm 13.64$ & 22 \\
Caner fish (Barbus capito) & $43.2 \pm 5.11$ & $648.6 \pm 15.70$ & 21 \\
Common carp (Cyprinus carpio) & $31.2 \pm 1.46$ & $337.2 \pm 10.88$ & 25 \\
Tigris scraper (Capoeta umbla) & $32.8 \pm 2.48$ & $385.1 \pm 13.53$ & 29 \\
\hline
\end{tabular}

The amounts of metal ( $\mathrm{Al}, \mathrm{As}, \mathrm{Cr}, \mathrm{Cu}, \mathrm{Fe}, \mathrm{Mn}, \mathrm{Ni}, \mathrm{Pb}$, and $\mathrm{Zn}$ ) concentrations determined in the gill, liver, and muscle tissues of the Caner fish, Tigris scraper, grass carp and common carp that were caught in the Tercan Dam Lake are given in the Tables $6,7,8$ and 9 , respectively.

Table 6. Maximum, minimum, mean values $(\mathrm{mg} / \mathrm{kg})$, and standard deviation values of the metals measured in muscle, liver, and gill tissues of the Caner fish (Barbus capito)

\begin{tabular}{c|c|c|c|c|c|c|c|c|c|c|c|c}
\hline Tissue & \multicolumn{3}{|c|}{ MUSCLE } & \multicolumn{4}{c|}{ LIVER } & \multicolumn{4}{c}{ GILL } \\
\hline Metal & Min & Max & Mean & St. dev. & Min & Max & Mean & St. dev. & Min & Max & Mean & St. dev. \\
\hline $\mathrm{Al}$ & - & - & - & - & 0.906 & 7.817 & 2.953 & 0.126 & 0.145 & 3.804 & 1.375 & 0.144 \\
$\mathrm{As}$ & - & - & - & - & 0.021 & 0.187 & 0.057 & 0.009 & 0.032 & 0.394 & 0.124 & 0.028 \\
$\mathrm{Cr}$ & 0.087 & 0.192 & 0.106 & 0.034 & 0.031 & 0.304 & 0.084 & 0.005 & 0.027 & 1.136 & 0.398 & 0.052 \\
$\mathrm{Cu}$ & 0.008 & 4.284 & 0.882 & 0.013 & 0.435 & 57.114 & 15.888 & 0.216 & 0.744 & 60.003 & 11.119 & 2.187 \\
$\mathrm{Fe}$ & 8.270 & 124.041 & 43.638 & 1.020 & 16.496 & 918.684 & 420.160 & 8.320 & 16.496 & 679.166 & 195.062 & 5.792 \\
$\mathrm{Mn}$ & 0.017 & 0.571 & 0.343 & 0.044 & 0.562 & 18.523 & 7.662 & 0.672 & 0.529 & 16.656 & 5.714 & 0.544 \\
$\mathrm{Ni}$ & - & - & - & - & 0.004 & 0.173 & 0.042 & 0.006 & 0.028 & 0.741 & 0.213 & 0.016 \\
$\mathrm{~Pb}$ & - & - & - & - & 0.016 & 0.227 & 0.090 & 0.017 & 0.008 & 0.067 & 0.032 & 0.008 \\
$\mathrm{Zn}$ & 21.048 & 237.530 & 77.936 & 4.050 & 0.334 & 241.328 & 88.507 & 3.074 & 0.334 & 241.328 & 91.691 & 1.935 \\
\hline
\end{tabular}

Table 7. Maximum, minimum, mean values $(\mathrm{mg} / \mathrm{kg})$, and standard deviation values of the metals measured in muscle, liver, and gill tissues of the Tigris scraper (Capoeta umbla)

\begin{tabular}{c|c|c|c|c|c|c|c|c|c|c|c|c}
\hline Tissue & \multicolumn{4}{|c|}{ MUSCLE } & \multicolumn{4}{c|}{ LIVER } & \multicolumn{4}{c}{ GILL } \\
\hline Metal & Min & Max & Mean & St. dev. & Min & Max & Mean & St. dev. & Min & Max & Mean & St. dev. \\
\hline $\mathrm{Al}$ & 7.613 & 57.754 & 20.009 & 4.270 & 37.087 & 215.078 & 90.044 & 11.670 & 44.105 & 199.086 & 96.595 & 7.749 \\
$\mathrm{As}$ & - & - & - & - & 0.087 & 0.479 & 0.160 & 0.077 & 0.045 & 0.601 & 0.186 & 0.091 \\
$\mathrm{Cr}$ & 0.009 & 0.054 & 0.023 & 0.006 & 0.753 & 8.715 & 2.088 & 0.723 & 0.317 & 12.593 & 2.455 & 0.613 \\
$\mathrm{Cu}$ & 0.108 & 1.091 & 0.239 & 0.082 & 49.347 & 358.440 & 141.470 & 6.078 & 0.447 & 1.928 & 0.378 & 0.170 \\
$\mathrm{Fe}$ & 1.795 & 43.138 & 8.986 & 1.708 & 117.448 & 1512.825 & 486.326 & 14.719 & 27.623 & 122.437 & 74.916 & 6.471 \\
$\mathrm{Mn}$ & 3.186 & 29.138 & 9.149 & 3.485 & 26.678 & 120.188 & 61.528 & 3.271 & 9.873 & 45.415 & 19.671 & 2.483 \\
$\mathrm{Ni}$ & - & - & - & - & 0.953 & 6.910 & 2.278 & 0.240 & 0.523 & 7.812 & 1.667 & 0.754 \\
$\mathrm{~Pb}$ & 0.316 & 2.281 & 0.640 & 0.150 & 0.520 & 3.739 & 2.074 & 1.141 & 0.364 & 1.733 & 0.547 & 0.050 \\
$\mathrm{Zn}$ & 3.832 & 54.958 & 11.703 & 2.165 & 3.180 & 69.201 & 34.972 & 5.659 & 12.385 & 75.248 & 37.777 & 3.762 \\
\hline
\end{tabular}


Table 8. Maximum, minimum, mean values $(\mathrm{mg} / \mathrm{kg})$, and standard deviation values of the metals measured in muscle, liver, and gill tissues of the Grass carp (Ctenopharyngodon idella)

\begin{tabular}{c|c|c|c|c|c|c|c|c|c|c|c|c}
\hline Tissue & \multicolumn{4}{|c|}{ MUSCLE } & \multicolumn{4}{c|}{ LIVER } & \multicolumn{4}{c}{ GILL } \\
\hline Metal & Min & Max & Mean & St. dev. & Min & Max & Mean & St. dev. & Min & Max & Mean & St. dev. \\
\hline $\mathrm{Al}$ & 1.598 & 8.021 & 3.069 & 0.740 & 2.003 & 40.217 & 19.322 & 3.161 & 2.714 & 19.357 & 10.136 & 5.983 \\
$\mathrm{As}$ & - & - & - & - & - & - & - & - & 0.190 & 1.675 & 0.774 & 0.543 \\
$\mathrm{Cr}$ & - & - & - & - & 0.009 & 1.136 & 0.458 & 0.052 & 0.012 & 0.075 & 0.049 & 0.026 \\
$\mathrm{Cu}$ & 0.321 & 1.723 & 0.792 & 0.157 & 1.122 & 7.248 & 4.185 & 0.251 & 0.132 & 2.014 & 0.882 & 0.694 \\
$\mathrm{Fe}$ & 4.170 & 39.071 & 27.350 & 5.412 & 26.966 & 104.672 & 59.277 & 2.833 & 7.745 & 53.402 & 23.452 & 3.025 \\
$\mathrm{Mn}$ & 0.003 & 0.441 & 0.014 & 0.001 & 0.617 & 6.218 & 2.859 & 0.202 & 4.021 & 11.116 & 7.349 & 2.596 \\
$\mathrm{Ni}$ & - & - & - & - & - & - & - & - & 0.019 & 0.205 & 0.122 & 0.065 \\
$\mathrm{~Pb}$ & 0.030 & 0.991 & 0.318 & 0.026 & 0.013 & 0.624 & 0.455 & 0.146 & 0.017 & 0.256 & 0.116 & 0.011 \\
$\mathrm{Zn}$ & 8.763 & 40.137 & 18.922 & 1.257 & 5.823 & 61.673 & 23.709 & 0.193 & 79.397 & 259.631 & 164.827 & 5.676 \\
\hline
\end{tabular}

Table 9. Maximum, minimum, mean values $(\mathrm{mg} / \mathrm{kg})$, and standard deviation values of the metals measured in muscle, liver, and gill tissues of the Common carp (Cyprinus carpio)

\begin{tabular}{c|c|c|c|c|c|c|c|c|c|c|c|c}
\hline Tissue & \multicolumn{4}{|c|}{ MUSCLE } & \multicolumn{5}{c|}{ LIVER } & \multicolumn{4}{c}{ GILL } \\
\hline Metal & Min & Max & Mean & St. dev. & Min & Max & Mean & St. dev. & Min & Max & Mean & St. dev. \\
\hline $\mathrm{Al}$ & 13.294 & 266.814 & 193.973 & 12.270 & 456.053 & 1120.483 & 807.121 & 9.627 & 7.575 & 97.435 & 39.624 & 2.092 \\
$\mathrm{As}$ & - & - & - & - & 0.057 & 0.449 & 0.265 & 0.146 & 0.057 & 0.923 & 0.383 & 0.083 \\
$\mathrm{Cr}$ & 0.198 & 1.336 & 0.592 & 0.445 & 0.078 & 2.608 & 1.409 & 0.011 & 0.314 & 2.692 & 0.918 & 0.042 \\
$\mathrm{Cu}$ & - & - & - & - & 17.069 & 100.169 & 46.023 & 2.831 & 0.789 & 6.045 & 2.695 & 0.517 \\
$\mathrm{Fe}$ & 10.766 & 194.636 & 87.463 & 7.210 & 450.917 & 1098.847 & 764.449 & 4.261 & 26.848 & 742.849 & 330.265 & 7.924 \\
$\mathrm{Mn}$ & 6.273 & 24.114 & 15.193 & 6.603 & 1.749 & 39.443 & 26.754 & 5.254 & 7.760 & 104.033 & 34.735 & 0.903 \\
$\mathrm{Ni}$ & 0.025 & 0.854 & 0.326 & 0.092 & 0.326 & 3.091 & 2.584 & 1.133 & 0.398 & 1.300 & 0.569 & 0.131 \\
$\mathrm{~Pb}$ & - & - & - & - & 0.279 & 0.988 & 0.534 & 0.253 & 0.534 & 1.370 & 0.962 & 0.253 \\
$\mathrm{Zn}$ & 4.219 & 11.731 & 8.301 & 2.490 & 23.148 & 109.507 & 52.752 & 7.153 & 11.007 & 0.945 & 4.264 & 1.327 \\
\hline
\end{tabular}

It was determined that the metal accumulation in the muscle tissues of Caner fish was $\mathrm{Zn}>\mathrm{Fe}>\mathrm{Cu}>\mathrm{Mn}>\mathrm{Cr}$, while the accumulation in the liver tissues of the same species was $\mathrm{Fe}>\mathrm{Zn}>\mathrm{Cu}>\mathrm{Mn}>\mathrm{Al}>\mathrm{Pb}>\mathrm{Cr}>\mathrm{As}>\mathrm{Ni}$, and the accumulation in its gill tissues was $\mathrm{Fe}>\mathrm{Zn}>\mathrm{Cu}>\mathrm{Mn}>\mathrm{Al}>\mathrm{Cr}>\mathrm{Ni}>\mathrm{As}>\mathrm{Pb}$. Additionally, it was determined that the accumulation of $\mathrm{Al}, \mathrm{As}, \mathrm{Ni}$, and $\mathrm{Pb}$ metals in the muscle tissues of the Caner fish were lower than the analysis limitations (Table 6). It was determined that the metal accumulation in the muscle tissues of Tigris scraper was $\mathrm{Al}>\mathrm{Zn}>\mathrm{Mn}>\mathrm{Fe}>\mathrm{Pb}>\mathrm{Cu}>\mathrm{Cr}$, while the accumulation in the liver tissues of the same species was $\mathrm{Fe}>\mathrm{Cu}>\mathrm{Al}>\mathrm{Mn}>\mathrm{Zn}>\mathrm{Cr}>\mathrm{Ni}>\mathrm{Pb}>\mathrm{As}$, and the accumulation in its gill tissues was $\mathrm{Al}>\mathrm{Fe}>\mathrm{Zn}>\mathrm{Mn}>\mathrm{Cr}>\mathrm{Ni}>\mathrm{Pb}>\mathrm{Cu}>$ As. Additionally, it was determined that the accumulation of As and Ni metals in the muscle tissues of the Tigris scraper were lower than the analysis limitations (Table 7). It was determined that the metal accumulation in the muscle tissues of grass carp was $\mathrm{Fe}>\mathrm{Zn}>\mathrm{Cu}>\mathrm{Al}>\mathrm{Pb}>$, while the accumulation in the liver tissues of the same species was $\mathrm{Fe}>\mathrm{Zn}>\mathrm{Al}>\mathrm{Cu}>\mathrm{Mn}>\mathrm{Cr}>\mathrm{Pb}$, and the accumulation in its gill tissues was $\mathrm{Zn}>\mathrm{Fe}>\mathrm{Al}>\mathrm{Mn}>\mathrm{Cu}>\mathrm{As}>\mathrm{Ni}>\mathrm{Pb}>\mathrm{Cr}$. Additionally, it was determined that the accumulation of As, $\mathrm{Cr}$, and Ni metals in the muscle tissues of the grass carp, and those of As and $\mathrm{Ni}$ metals in the liver tissues of it were lower than the analysis limitations (Table 8). It was determined that the metal accumulation in the muscle tissues of 
common carp was $\mathrm{Al}>\mathrm{Fe}>\mathrm{Mn}>\mathrm{Zn}>\mathrm{Cr}>\mathrm{Ni}$, while the accumulation in the liver tissues of the same species was $\mathrm{Al}>\mathrm{Fe}>\mathrm{Zn}>\mathrm{Cu}>\mathrm{Mn}>\mathrm{Ni}>\mathrm{Cr}>\mathrm{Pb}>\mathrm{As}$, and the accumulation in its gill tissues was $\mathrm{Fe}>\mathrm{Al}>\mathrm{Mn}>\mathrm{Zn}>\mathrm{Cu}>\mathrm{Pb}>\mathrm{Cr}>\mathrm{Ni}>\mathrm{As}$. Additionally, it was determined that the accumulation of $\mathrm{As}, \mathrm{Cr}$, and $\mathrm{Ni}$ metals in the muscle tissues of the common carp were lower than the analysis limitations (Table 9).

There have been numerous research studies conducted in various parts of the world on the accumulation of metals in fish tissues and their detrimental effects on the tissues (Moiseenko and Kudryavtseva, 2001; Uysal et al., 2008; Kirici et al., 2013b, 2016b; ElMoselhy et al., 2014; Baharom and Ishak, 2015; Bosch et al., 2016; La Colla et al., 2017, 2018). For instance, in a study conducted on Avşar Lake (Turkey), Öztürk et al. (2009) examined the metal accumulation concentrations in the muscle, liver, and gill tissues of the Carp, and as the conclusion of the study, it was determined that the Fe metal had the highest accumulation level while $\mathrm{Cd}$ had the least. The ranking of metal accumulation in the tissues was determined as $\mathrm{Fe}>\mathrm{Cu}>\mathrm{Pb}>\mathrm{Ni}>\mathrm{Cr}>\mathrm{Cd}$ in the muscle, and $\mathrm{Fe}>\mathrm{Cu}>\mathrm{Ni}>\mathrm{Pb}>\mathrm{Cr}>\mathrm{Cd}$ in the gill and liver. Malik et al. (2010) determined the seasonal changes of some certain heavy metals $(\mathrm{Cd}, \mathrm{Cr}, \mathrm{Cu}, \mathrm{Hg}, \mathrm{Ni}, \mathrm{Pb}$, $\mathrm{Zn}$ ) in the muscle, liver, gill, and kidneys of Labeo rohita and grass carp species in the Bhopal Lake (India). It was determined that, for the both fish species, the metals accumulated mostly in the livers and at the least levels in the muscles. While the highest accumulated metal in the fish was $\mathrm{Zn}$, it was determined that $\mathrm{Hg}$ had the lowest level of accumulation. Taweel et al. (2013), examined the accumulation of $\mathrm{Cu}, \mathrm{Cd}, \mathrm{Ni}, \mathrm{Pb}$, and $\mathrm{Zn}$ in the muscle, liver, and gills of Tilapia fish (Oreochromis niloticus) living in the Langat River and Engineering Lake. As the conclusion of the study, it was determined that the accumulation ranking of the heavy metals was $\mathrm{Cu}>\mathrm{Zn}>\mathrm{Ni}>\mathrm{Pb}>\mathrm{Cd}$ in the liver samples, while it was $\mathrm{Zn}>\mathrm{Ni}>\mathrm{Cu}>\mathrm{Pb}>\mathrm{Cd}$ in the gill and muscle samples. The researchers reported that there was no risk in consumption of Tilapia fish.

The metal amounts determined in the muscle, liver, and gill tissues of the fish were compared to the values determined by the WHO, MFAL, and USEPA. As a result, it was determined that, in the muscle tissue of Caner fish, the $\mathrm{Zn}$ amount was higher than the acceptable level determined by the MFAL, the Fe amount in the liver tissue was higher than those of the MFAL and USEPA, the Mn amount was higher than that of the WHO, and the $\mathrm{Zn}$ amount was higher than that of the MFAL. Similarly, it was determined that, in the gill tissue of Caner fish, Mn amount was higher than the acceptable level determined by the WHO, and the $\mathrm{Zn}$ amount was higher than that of the MFAL. As per the muscle tissue of Tigris scraper, it was determined that the Mn amount was higher compared to the acceptable level determined by the WHO; in the liver tissue of Tigris scraper, it was determined that the $\mathrm{Cu}$ amount was higher compared to the acceptable level determined by the WHO, MFAL, and USEPA; as per the gill tissue of Tigris scraper, the Mn amount was higher compared to the level of WHO, and Ni amount was higher compared to the levels determined by the MFAL and WHO.

In the liver tissues of the grass carp, the Mn amount was higher than the acceptable level determined by the WHO, in its gill tissues, the Mn amount was higher than that of the WHO, and $\mathrm{Zn}$ amount was higher than those of WHO and MFAL. In the muscle tissues of the common carp, the Mn amount was higher than the acceptable level determined by the WHO for the fish tissues, and the amount of Ni was higher than that of MFAL; in its liver tissues, the Cn amount was higher than that of the WHO, MFAL, and USEPA, and the Mn amount was higher than that of WHO; as per the gill tissues, 
the $\mathrm{Zn}$ and $\mathrm{Ni}$ amounts were higher than those of WHO and MFAL, Mn amount was higher than that of WHO, and Ni amount than that of MFAL.

\section{Conclusion}

As the conclusion of the study, when the metal concentrations determined in the muscle, liver, and gill tissues of fish were compared to the values determined by the WHO, MFAL, and USEPA, it was determined that the metal concentrations determined in the fish tissues were higher than the acceptable levels. It is an important case for the human health, since the muscle, which is consumed by human beings, had a metal concentration over the acceptable levels. Accumulation of metals in tissues directly influences the blood parameters, enzyme activities, growth, and development of the living being. Although numerous factors influence the existence of metals in the waters, undoubtedly the most important factor is the human activities. The water resources are contaminated particularly due to domestic waste, industrial waste, and agricultural activities. At this point, particularly people living around the water resources should be informed by the authorities. Additionally, necessary precautions should be taken against the wastes being released to the water resources from the industrial facilities and these measurements should be supervised by the authorities. Also, a potential danger may exist in the future, depending on the agricultural development in this region. As the Tercan Dam Lake is also used for agricultural irrigation purposes, performance of pollution researches at certain periods is of significance for both environment and public health.

Acknowledgements. This study was supported by the Erzincan Binali Yıldirım University, Scientific Research Projects Unit (Project no: FHD-2017-514). We would like to present our sincere thanks to the Erzincan Binali Yıldırım University, Scientific Research Projects Unit for their supports.

\section{REFERENCES}

[1] Ahmad, K., Azizullah, A., Shama, S., Khattak, M. N. K. (2014): Determination of heavy metal contentes in water, sediments, and fish tissues of Shizothorax plagiostomus in river Panjkora at Lower Dir, Khyber Pakhtunkhwa, Pakistan. - Environment Monitoring Assessment 186: 7357-7366.

[2] Al-Saadi, H. A., Al-Lami, A. A., Hassan, F. A., Al-Dulymi, A. A. (2002): Heavy metals in water, suspended particles, sediments and aquatic plants of Habbaniya Lake, Iraq. International Journal of Environmental Studies 59: 589-598.

[3] An, Y. J., Kampbell, D. H. (2003): Total, dissolved, and bioavailable metals at Lake Texoma Marinas. - Environmental Pollution 122: 253-259.

[4] Baharom, Z. S., Ishak, M. Y. (2015): Determination of heavy metal accumulation in fish species in Galas River, Kelantan and Beranang mining pool, Selangor. - Procedia Environmental Sciences 30: 320-325.

[5] Başyiğit, B., Tekin-Özan, S. (2013): Concentrations of some heavy metals in water, sediment and tissues of Pikeperch (Sander lucioperca) from Karataş Lake related to physico-chemical parameters, fish size and seasons. - Polish Journal of Fisheries and Aquatic Sciences 22: 11-22.

[6] Bosch, A. C., O’Neill, B., Sigge, G. O., Kerwath, S. E., Hoffman, L. C. (2016): Heavy metal accumulation and toxicity in Smoothhound (Mustelus mustelus) shark from Langebaan Lagoon, South Africa. - Food Chemistry 190: 871-878. 
[7] Elbeshti, R. T. A., Elderwish, N. M., Abdelali, K. M. K., Taştan, Y. (2018): Effects of heavy metals on fish. - Menba Journal of Fisheries Faculty 4: 36-47.

[8] El-Moselhy, K. M., Othman, A. I., Abd El-Azem, H., El-Metwally. M. E. A. (2014): Bioaccumulation of heavy metals in some tissues of fish in the Red Sea, Egypt. Egyptian Journal of Basic and Applied Sciences 1: 97-105.

[9] Erdoğrul, O., Ateş, D. A. (2006): Determination of cadmium and copper in fish samples from Sir and Menzelet Dam Lake, Kahramanmaraş, Turkey. - Environmental Monitoring and Assessment 117: 281-290.

[10] Fergusson, F. E. (1990): The Heavy Elements: Chemistry, Environmental Impact and Health Effects. - Pergamon Press, Oxford, UK.

[11] Kir, İ., Özan, S. T., Tuncay, T. (2007): The seasonal variations of some heavy metals in Kovada Lake's water and sediment. - Ege University Journal of Fisheries and Aquatic 24: 155-158 (in Turkish)

[12] Kirici, M., Taysı, M. R., Bengü, A. Ş., İspir, Ü. (2013a): Determination of some metal levels in Capoeta capoeta umbla (Heckel, 1843) caught from Murat River. - Iğdır University Journal of the Institute of Science and Technology 3: 85-90 (in Turkish).

[13] Kirici, M., Taysi, M. R., Bengü, A. Ş., İspir, Ü. (2013b): Determination of some metal concentrations in muscle tissues of Capoeta trutta (Heckel, 1843) caught from Murat River. - Erzincan University Journal of Science and Technology 6: 115-124 (in Turkish).

[14] Kirici, M., Kirici, M., Beydemir, Ş., Atamanalp, M. (2016a): Purification of carbonic anhydrase from Capoeta umbla (Heckel, 1843) gills and toxicological effects of some metals on enzyme activity. - Turkish Journal of Fisheries and Aquatic Sciences 16: 169175.

[15] Kirici, M., Kirici, M., Demir, Y., Beydemir, S., Atamanalp, M. (2016b): The effects of $\mathrm{Al}^{3+}$ and $\mathrm{Hg}^{2+}$ on glucose 6-phosphate dehydrogenase from Capoeta umbla kidney. Applied Ecology And Environmental Research 14: 253-264.

[16] Kirici, M., Atamanalp, M., Kirici, M., Beydemir, Ş. (2017a): In vitro effects of some metal ions on glutathione reductase in the gills and liver of Capoeta trutta. - Regulatory Mechanisms in Biosystems 8: 66-70.

[17] Kirici, M., Turk, C., Caglayan, C., Kirici, M. (2017b): Toxic effects of copper sulphate pentahydrate on antioxidant enzyme activities and lipid peroxidation of freshwater fish Capoeta umbla (Heckel, 1843) tissues. - Applied Ecology and Environmental Research 15: 1685-1696.

[18] Köse, E., Uysal, K. (2008): The comparison of heavy metal accumulation ratios in muscle, skin and gill of non-maturated common carp (Cyprinus carpio L., 1758). Journal of Science and Technology of Dumlupinar University 17: 19-26.

[19] Kurtoğlu, S. (2006): The investigation of some chemical parameters and seasonal variations of sediment in Lake Uluabat. - Master Thesis, Uludağ University, Institute of Science and Technology, Bursa, Turkey (in Turkish).

[20] La Colla, N. S., Botté, S. E., Marcovecchio, J. E. (2018): Metals in coastal zones impacted with urban and industrial wastes: Insights on the metal accumulation pattern in fish species. - Journal of Marine Systems 181: 53-62.

[21] La Colla, N. S., Botté, S. E., Oliva, A. L., Marcovecchio, J. E. (2017): Tracing Cr, Pb, Fe and $\mathrm{Mn}$ occurrence in the Bahía Blanca estuary through commercial fish species. Chemosphere 175: 286-293.

[22] Malik, N., Biswas, A. K., Qureshi, T. A., Borana, K., Virha, R. (2010): Bioaccumulation of heavy metals in fish tissues of a freshwater Lake of Bhopal. - Environmental Monitoring and Assessment 160: 267-76.

[23] Moiseenko, T. I., Kudryavtseva. L. P. (2001): Trace metal accumulation and fish pathologies in areas affected by mining and metallurgical enterprises in the Kola Region, Russia. - Environmental Pollution 114: 285-297. 
[24] Özmen, H., Külahçı, F., Çukurovalı, A., Doğru, M. (2004): Concentrations of heavy metal and radioactivity in surface water and sediment of Hazar Lake (Elazığ, Turkey). Chemosphere 55: 401-408.

[25] Öztürk, M., Özözen, G., Minareci, O., Minareci, E. (2009): Determination of heavy metals in fish, water and sediments of Avsar Dam Lake in Turkey. - Iranian Journal of Environmental Health Science and Engineering 6: 73-80.

[26] Salomans, W., Rooij, N. M., Kerdijk, H., Bril, J. (1987): Sediments as a source for contaminants. - Hydrobiologia 149: 13-30.

[27] Sökmen, T. Ö., Güneş, M., Kirici, M. (2018): Determination of heavy metal levels in water, sediment and Capoeta umbla tissues of Karasu River (Erzincan). - Turkish Journal of Agricultural and Natural Sciences 5: 578-588 (in Turkish).

[28] Sönmez, A. Y., Kadak, A. E., Özdemir, R. C., Bilen, S. (2016): Establishing on heavy metal accumulation in some economically important fish species captured from Kastamonu Costal. - Alınteri 31: 84-90.

[29] Tao, Y., Yuan, Z., Wei, M., Xiaona, H. (2011): Characterization of heavy metals in water and sediments in Taihu Lake, China. - Environmental Monitoring and Assessment 184: 4367-4382.

[30] Taweel, A., Shuhaimi-Othman, M., Ahmad, A. K. (2013): Assessment of heavy metals in Tilapia fish (Oreochromis niloticus) from the Langat River and Engineering Lake in Bangi, Malaysia and evaluation of the health risk from Tilapia consumption. Ecotoxicology and Environmental Safety 93: 45-51.

[31] Tekin-Özan, S., Aktan, N. (2012): Relationship of heavy metals in water, sediment and tissues with total lenght, weight and seasons of Cyprinus carpio L., 1752 from Işıklı Lake (Turkey). - Pakistan Journal of Zoology 44: 1405-1416.

[32] Tekin-Özan, S., Kır, İ. (2005): Comparative study on the accumulation of heavy metals in different organs of tench (Tinca tinca L., 1758) and plerocercoids of its endoparasite Ligula intestinalis. - Parasitology Research 97: 156-159.

[33] Tekin-Özan, S., Kır, İ., Barlas, M. (2004): Determination of some heavy metals in water of Kovada Lake (Isparta) and Pike Perch (Stizostedion lucioperca L., 1758). - 1st National Limnology Workshop, Istanbul University, 16-19 May 2004, Turkey (in Turkish).

[34] Tekin-Özan, S., Kır, İ., Tuncay, Y. (2007): The seasonal variations of some heavy metals in Kovada Lake's water and sediment. - Ege University Journal of Fisheries and Aquatic Sciences 24: 155-158 (in Turkish).

[35] Usero, J., Izquierdo, C., Morillo, J., Gracia, I. (2003): Heavy metals in fish (Solea vulgaris, Anguilla anguilla and Liza aurata) from salt marshes on the Southern Atlantic Coast of Spain. - Environmental International 1069: 1-8.

[36] Uysal, K., Emre, Y., Köse, E. (2008): The determination of heavy metal accumulation ratios in muscle, skin and gills of some migratory fish species by inductively coupled plasma-optical emission spectrometry (ICP-OES) in Beymelek Lagoon (Antalya/Turkey). - Microchemical Journal 90: 67-70.

[37] Venkatesha, R., Somashekar, R. K., Prakash, K. L. (2012): Heavy metal status of sediment in River Cauvery, Karnataka. - Environmental Monitoring and Assessment 184: 361-73.

[38] Yarsan, E., Bilgili, A., Türel, İ. (2000): Heavy metal levels in Mussels (Unio stevenianus Krynicki) obtained from Van Lake. - Turkish Journal of Veterinary and Animal Sciences 24: 93-96 (in Turkish). 